\title{
石巻市雄勝町における災害危険区域内住民の居住地移動の実態
}

\section{A study on the migration of the inhabitants in the disaster hazard area in Ogatsu town, Ishinomaki city}

荒木 笙子* 秋田 典子*

Shoko ARAKI Noriko AKITA

\begin{abstract}
Ishinomaki city was damaged by the tsunami at the Great East Japan Earthquake, and the flooded area was the largest among the disaster cities. In Ogatsu, all of the centers of the town became the place that people cannot live, so population significantly decrease. The purpose of this research is to clarify the migration of the inhabitants in Ogatsu. We analyzed the living situation of temporary and permanent of the 618 households who lived in the old center of the Ogatsu area. Through this research, we have revealed the following things; The Ogatsu area could not secure the residence within the district because it was difficult to obtain temporary housing within the same area. Among the 618 households, the Ogatsu district occupied $11.2 \%$ in the temporary period and $12.5 \%$ in the permanent period. Although the residents of the Ogatsu area moved to the outside during the temporary period, they intend to reside again. But for the households who could not return, large-scale housing complexes in the Kahoku district took on them. We want to clarify the difference in residential trends due to the presence or absence of designation of disaster hazard area.
\end{abstract}

Keywords: the Great East Japan Earthquake, tsunami affected area, disaster hazard area, residence movement, Ogatsu town in Ishinomaki city

キーワード：東日本大震災，津波被災地，災害危険区域，居住地移動，石巻市雄勝町

\section{1. 研究の背景と目的}

2011 年 3 月 11 日，東日本大震災が発生した。東北地方の沿岸 地域では青森県から千葉県までの 6 県において, 56, 100ha が津波 による浸水被害を受けた ${ }^{1)}$ 。

東日本大震災の復興事業において特徴的なのが，元の居住地を 居住系建築物の新築と増改築が禁止される災害危険区域に指定し, そのうち集団移転の促進が適当であると認められる場所を移転促 進区域に指定，別の安全な高台に集団移転するという防災集団移 転促進事業（以下，防集事業）が数多く採用されたことである。 被害の集中した岩手・宮城・福島の 3 県において，震災前と同じ 場所で再建を行う被災市街地復興土地区画整理事業（以下，土地 区画整理事業) は60 地区 820. 1ha で実施されたのに対し, 防集事 業は330 地区で 1716. 2ha で事業が実施されており, 土地区画整理 事業より地区数は 5.5 倍, 面積は 2.1 倍である ${ }^{2)}$ 。防集事業の住 宅団地の規模は 10 戸以上，移転希望者が 20 戸を超える場合は半 数以上とされているが，東日本大震災後の特例により 5 戸以上に 緩和された ${ }^{3)}$ 。ただし，移転先の用地確保が困難である場合，用 地取得に時間がかかるため，造成が待てずに他の場所での再建を 決める人が生じている ${ }^{4)}$ 。また一方で，移転元地となった災害危 険区域などの低平地と呼ばれる空間においては，具体的な土地利 用が定まっていないケースが多く, 復興事業期間終了後にも課題 として残されることが懸念されている5)。

東日本大震災後に指定された災害危険区域に関連する既往研究 には，被災自治体における災害危険区域の指定方法を整理したも のがある ${ }^{7)}$ 。この研究では災害危険区域の持つ意義には「将来的 な自然災害リスクの軽減」と「被災者支援」があり，多くの自治 体では被害状況や住民意向，地形的・時期的制約から区域指定を 行なっていること，区域基淮・浸水深基淮・ゾーン基準の 3 つの 基準の組み合わせでリスク軽減と被災者支援の両立を図っている ことを明らかにしているほか，低密市街地形成の問題が深刻化す る可能性を示唆している。また災害危険区域の指定と被害度合い,
可住地割合の関係を数值に基づき分析し，地域ごとの特性を比較 した研究も存在する。その結果リアス式地形で可住地割合の低い 三陸沿岸部は災害危険区域指定率が高く, 中でも岩手県より宮城 県北部のほうが浸水面積に対する災害危険区域の指定率が高いこ とが明らかにされた ${ }^{8)}$ 。

震災後の住民の居住地選択については無事業で現地復興が行わ れた場所の住民の移動を追った研究がある ${ }^{9)}$ 。面的な復興事業を 行わなかった場合は，約 60\%の住民が震災前と同じ場所に居住し ており，移動した住民も内陸エリアではなく同一地区内に留まる 住民が多いことが明らかにされた。また事業を導入した場所につ いての研究は，土地区画整理事業が住民の居住地移動に与えた影 響を明らかにした研究がある ${ }^{10)}$ 。この研究では被害の度合いにか かわらず，すぐに現地再建が可能であれば約 90\%の住民が現地再 建を行い，地域外一の流出がないことが明らかにされた。

住民の住宅再建意向の変化については, 石巻市市街地部におい て災害公営住宅入居登録までの住宅再建意向変化と要因を分析し

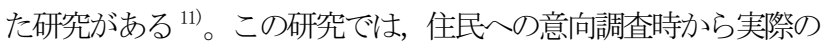
入居申込までに立地希望が変化していることが明らかにされてい る。震災前に不便な場所に居住していた世帯は, 仮設住宅で便利 な場所一移動すると移動先に本設を希望する世帯も増える一方で, 時間の経過に伴い恐怖心が和らぎ，震災前の場所一再居住を希望 する世帯も増える。しかし住宅の整備戸数の決定段階ではそれよ り前の希望調査結果を反映するため, 最終的に新市街地の整備戸 数が多くなり，震災前居住地に再居住できる世帯が減少した。意 向調査の結果だけではなく, 自力再建が困難な層や自身で決定で きない層を想定する必要性が明らかにされた。

以上より，これまで炎害危険区域の指定経緯や自治体単位の地 域特性の傾向, 現地復興が行われた地域や土地区画整理事業が行 われた場所における居住地移動を追った研究，住民の住宅再建意 向の変化についての研究はあるが，災害危険区域内に従前の居住 地がある世帯の居住地移動の実態を特定の地域に着目し明らかに

*千葉大学大学院園芸学研究科 
した研究はない。

本研究では東日本大震災後，町の中心部全体が災害危険区域に 指定された石巻市半島エリアの雄勝町に着目し，災害危険区域内 住民がどのように居住地移動を行なったのか，仮設と最終的な居 住地の地区別戸数や位置, 世帯人数等の分析を行いながら明らか にすることを目的とする。

\section{2. 研究の対象と方法}

\section{(1) 研究の対象}

本研究では宮城県石巻市の半島エリアに位置する旧雄勝町中心 部を対象とし，災害危険区域内居住世帯の移動動向について分析 を行う。石巻市の市域面積は55, 458ha であり, 国勢調査によると 震災前 2010 年の人口は 160,826 人, 世帯数は 57,871 , 震災後 2015 年の人口は 147,214 人，世帯数は 56,819 と，人口は 13,612 人， 世帯数は 1, 052 減少した（震災後の世帯分離のため人口に対し世 帯の減少が少ない)。市内人口は 1985 年をピークに減少している。

石巻市は 2005 年に旧石巻市に隣接する桃生郡桃生町, 河北町, 河南町, 北上町, 雄勝町, 生鹿郡牛鹿町と合併し, 現在の市域と なった。本論文では，旧市町単位をそれぞれ，旧石巻市を本庁地 区，旧河北町を河北地区，旧河南町を河南地区，旧北上町を北上 地区，旧雄勝町を雄勝地区，旧牡鹿郡牛鹿町を牡鹿地区として扱 う。図-1 には合併後の 2005 年から 2015 年までの各地区の人口 変動を示す ${ }^{12)}$ 。特に震災前 2010 年から震災後 2015 年までの人口 増減率を見ると，雄勝地区が最も減少している。

\section{(2) 研究の方法}

2012 年より石巻市雄勝地区における参与観察を続け, 災害危険 区域における土地利用の現地調査を継続的に行なってきた。2015 年より石巻市雄勝総合支所と，低平地の活用などについての意見 交換やヒアリングを年間 10 回程度継続している。本研究では, 石 巻市雄勝総合支所との連携協定 ${ }^{13)}$ に基づき，石巻市雄勝総合支所 が雄勝地区の住民の居住地移動について記録した調査データの提 供を受け，分析を行った。また文献調査と，地図上での解析を行 うために津波浸水区域や災害危険区域等のデータを元にGIS を用 いた分析を行なった。

\section{3. 石巻市における復興事業}

\section{（1）石巻市の都市計画の概要と被災状況}

石巻市の本庁地区，河南地区，隣接する東松島市と女川町の一 部は石巻広域都市計画区域に指定されており，1970 年に線引きが 行われた。都市計画区域は本庁地区と河南地区，河北地区の 14, 513ha が指定されており，市域面積の 26.2\%にあたる。市街化 区域は本庁地区と河南地区の 3, 315.9ha（市域面積の6.0\%), 市街 化調整区域は同様に本庁地区と河南地区の 9,689. 1ha（市域面積 の $17.5 \%)$ が指定されている ${ }^{14)}$ 。雄勝地区と牡鹿地区はいずれも 1940 年ごろから都市計画区域に指定されていたが, 開発等が見込 めなかったことから, 合併前の 2002 年にいずれの都市計画区域も 廃止され，東日本大震災の発災時は都市計画区域外であった。

石巻市は津波による浸水面積が全被災自治体中最大であった。 市域面積の約 $13.1 \%$, 7, 300ha が浸水し，3,750 人の死者が発生し た ${ }^{15)}$ 。石巻市では旧市町単位で最低 1 箇所ずつ市役所の本庁や支

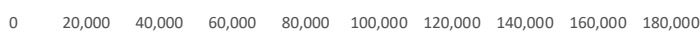

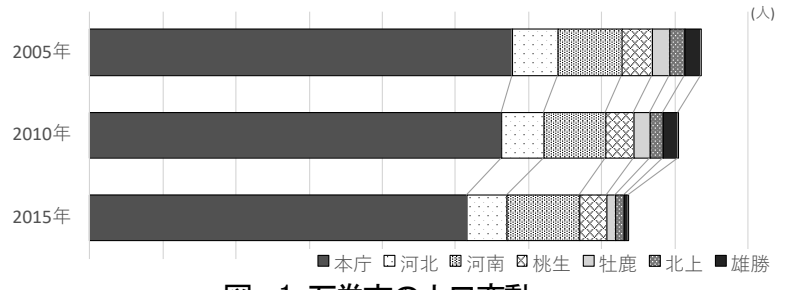

図-1 石巻市の人口変動



図一2 石巻市内の位置図

所・出張所が設けられ, 合併前の地域性が強く残っているため, 旧市町単位を基にした地区単位で復興事業を進めている。

図一2 に各地区の位置図と 2010 年と比較した 2015 年時点の人 口増减率を円グラフで示す ${ }^{16)}$ 。この結果, 市街地エリア, 半島エ リア，内陸エリアで震災後の人口増減率に異なる傾向が見られた ことから，以降の分析ではエリア別の傾向を踏まえながら旧市町 別の考察を行うこととした。市街地エリアは本庁地区の夕が該当 し, 市役所の本庁舎や主要駅の石巻駅を有し, 市の中心的な役割 を担っている。直接浸水被害を受け，人口は $10.7 \%$ 減少した。半 島エリアは北上地区, 河北地区, 雄勝地区, 牡鹿地区の 4 地区で ある。いずれも津波により大きな被害を受け, 2011 年 3 月の津波 浸水区域の全域が災害危険区域に指定された。人口は大幅に減少 しており，特に雄勝地区では 63.9\%の人口が減少した。雄勝地区 は合併以前の行政区域単位において, 全被災自治体中, 震災前後 で最も人口が減少した場所である。内陸エリアは桃生地区と河南 地区の 2 地区である。津波による被害はほとんどなく，河南地区 では市内で唯一人口が増加した。

\section{（2）土地利用に関する復興事業と区域指定}

石巻市は人口が多く建築主事を置いているため，市の権限で建 築制限の指定が可能である。石巻市は震災直後の 2011 年 4 月から 建築基淮法第 84 条による建築制限を行い，5 月から特例により本 庁地区の一部や雄勝地区の中心部にて建築制限を行った。9 月に 石巻市は全被災自治体の中で最も早く, 本庁地区の建築制限区域 を被災市街地復興推進地域に移行した。

2012 年 12 月には, 建築基淮法第 39 条に基づく災害危険区域の 区域指定が市街地エリアと半島エリアそれぞれで行われた。具体 的な基淮は条例に定められており, 居住系建築物, 宿泊施設, 病 院，児童福祉施設等の新築と建替え，増改築を禁止している。災 害危険区域は一度指定されると，原則として解除できない。

石巻市では市街地エリアと半島エリアにおいて災害危険区域の 指定基淮が異なる。市街地エリアは二線堤の機能を有する防災施 設の整備により，シミュレーション上津波による市街地エリアの 浸水を防ぐことができると判断されたため，防災施設から海側を 区域に定めた。

一方で半島エリアでは, 2011 年 3 月の津波浸水区域全域を対象 として区域が指定された。松本ら(2015) は半島エリアの災害危険 区域指定について「小規模な漁業集落が多く, 低平地一帯が壊滅 的な被害を受けて今後宅地を整備できるような土地がなく, 集落 全体で移転する傾向が強いため,このような指定に至った。(中略) 指定についての課題は特段生じていない。と述べている。 
表一1 に各地区における浸水区域と災害危険区域の指定面積と 対象世帯数を示す。浸水区域面積は宮城県土木部発表資料, 災害 危険区域面積と対象世帯数は読売新聞よりそれぞれ引用した ${ }^{17) 。 ~}$ シミュレーションを根拠として区域が指定された市街地エリアで は, 浸水区域の $10.6 \%$ が災害危険区域に指定された。一方 2011 年 3 月の津波浸水区域全域が指定の対象となった半島エリアでは, 浸水区域の $38.7 \%$ 爻售害危険区域に指定された。中でも海に面す る面積の大きい牡鹿地区は $96.5 \%$ ，雄勝地区は $100.0 \%$ とずれも ほぼ全域が指定された。

\section{（3）居住に関する事業}

\section{1）計画に位置付けられた方針}

石巻市は 2011 年 12 月に石巻市震災復興基本計画を策定した。 計画の中の「都市基盤の復旧・復興を推進するための主な施策」 の中では, 市街地エリアは土地区画整理事業と市街地再開発事業, 半島エリアは防災集団移転促進事業を導入することを示している。 地区別整備方針では，市街地エリアは多重防御による災害に強い まちづくりを行うこと，半島エリアはいずれの地区についても既 存の観光施設や自然環境を活かしてにぎわいの創出を図ることが 示された ${ }^{18)}$

\section{2) 仮設期}

市は半島エリアの住民に対して当初，応急仮設住宅（以下，仮 設住宅）の建設に際して半島エリアでの土地確保が難しいため, 市街地エリアの仮設住宅への入居を促した。しかし半島エリアの 住民による反対を受けたため，半島エリアでの仮設住宅の建設が 遅れて始まった ${ }^{19)}$ 。2011 年4 月下旬から仮設住宅への入居が開始 したが，当初入居可能な仮設住宅は本庁地区のみで，その後 5 月 以降に半島エリアの各地区の仮設住宅への入居と追加の建設が進 んだ。一方で仮設住宅への入居が待てない住民や，希望の地区に 入居できない住民は，希望地区以外の仮設住宅は選択せず，みな し仮設や賃貸住宅などへ移動した。このため仮設住宅の必要戸数 は時期により変動した ${ }^{20)} 。 2011$ 年 10 月 11 日に市内全ての避難所 が閉鎖された段階で，仮設住宅の入居が一旦終了した。

表一 2 に仮設住宅の着工戸数と, 2018 年 9 月 1 日時点での入居 戸数を示す ${ }^{21)}$ 。半島エリアの着工戸数は市街地エリアの半数以下 であった。最も着工戸数の少ない雄勝地区は地盤が硯の原材料の 玄昌石と呼ばれる硬い岩盤であるため，山を削った造成が困難で あった。雄勝地区には避難場所に使われたクリーンセンターや葬 祭場などの施設が存在したが，いずれも山の上にあり住民が日常 的には使用していない場所であった。

一方で雄勝地区の次に着工戸数の少ない北上地区の場合は，3 団地中 1 団地はにっこりサンパーク団地と呼ばれる，最大時 178 世帯が入居した団地である。震災前から中学校や総合グラウンド 等のスポーツ施設が集積していた。今後，復興事業で北上地区の 中心機能が集積予定である。このようなまとまった公共用地の存 在が，仮設期に地区内で住民を受け入れる大きな鍵となった ${ }^{22)}$ 。

震災から7年半が経過した 2018 年9月時点でも仮設住宅には市 内全体で 325 戸が居住を続けている。市街地エリアと比較して半 島エリアの方が仮設住宅に長期にわたり居住し続けている世帯の 割合が高い。

3）本設期

大規模な復興公営団地の整備が進む市街地エリアでは既存市街 地の土地区画整理事業の他，新しい市街地開発が行われ，大規模 な住民の受け皿としての役割を果たしている。新市街地は6 地区 122. 1ha が整備され，既存市街地の住居系用途は 5 地区 81. 7ha が 整備された。

コミュニティ単位の住民の受け血としては防集団地の整備があ る。表一 3 に地区数と戸数を示寸。 50 地区 1,214 戸が整備され， 2018 年 3 月末には全地区で整備が完了した ${ }^{23)}$ 。
表-1 石巻市各地区の浸水区域と災害危険区域指定状況

\begin{tabular}{|c|c|c|c|c|c|c|}
\hline 区分 & 地区 & $\begin{array}{c}\begin{array}{c}\text { 地区面積 } \\
\text { (ha) }\end{array} \\
\end{array}$ & $\begin{array}{c}\text { 浸水区域 } \\
\text { (ha) }\end{array}$ & $\begin{array}{l}\text { 災害危険 } \\
\text { 区域(ha) }\end{array}$ & $\begin{array}{l}\text { 災害危険区域 } \\
\text { /浸水区域(\%) }\end{array}$ & $\begin{array}{c}\text { 災害危険区域 } \\
\text { 対象世帯数 }\end{array}$ \\
\hline 市街地エリア & 本庁 & $13,704.0$ & 3960.0 & 421.0 & $10.6 \%$ & 3,911 \\
\hline \multirow{4}{*}{ 半島エリア } & 牡鹿 & $12,509.0$ & 227.0 & 219.0 & $96.5 \%$ & 705 \\
\hline & 雄勝 & $4,612.0$ & 152.0 & 152.0 & $100.0 \%$ & 1,142 \\
\hline & 北上 & $6,933.0$ & 974.0 & 352.0 & $36.1 \%$ & 491 \\
\hline & 河北 & $4,382.0$ & 1942.0 & 552.0 & $28.4 \%$ & 328 \\
\hline \multirow{2}{*}{ 内陸エリア } & 河南 & $6,098.0$ & 446.0 & 0.0 & $0.0 \%$ & 0 \\
\hline & 桃生 & $7,298.0$ & 0.0 & 0.0 & - & 0 \\
\hline \multicolumn{2}{|c|}{ 市街地エリア計 } & $13,704.0$ & $3,960.0$ & 421.0 & $10.6 \%$ & 3,911 \\
\hline \multirow{2}{*}{\multicolumn{2}{|c|}{$\begin{array}{l}\text { 半島エリア計 } \\
\text { 内陸エリア計 }\end{array}$}} & $28,436.0$ & $3,295.0$ & $1,275.0$ & $38.7 \%$ & 2,666 \\
\hline & & $13,396.0$ & 446.0 & 0.0 & $0.0 \%$ & 0 \\
\hline \multicolumn{2}{|c|}{ 合計 } & $55,536.0$ & $7,701.0$ & $1,696.0$ & $22.0 \%$ & 6,577 \\
\hline
\end{tabular}

表-2 各地区の応急仮設住宅着工件数

\begin{tabular}{|c|c|c|c|c|c|}
\hline \multirow{2}{*}{ 区分 } & \multirow{2}{*}{ 地区 } & \multirow{2}{*}{ 団地数 } & \multirow{2}{*}{ 着工戸数 } & \multicolumn{2}{|c|}{ 2018年9月1日時点 } \\
\hline & & & & 現戸数 & 入居戸数 \\
\hline 市街地エリア & 本庁 & 73 & 4,174 & 2,881 & 168 \\
\hline \multirow{4}{*}{ 半島エリア } & 牡鹿 & 18 & 445 & 160 & 0 \\
\hline & 雄勝 & 8 & 161 & 112 & 9 \\
\hline & 北上 & 3 & 234 & 56 & 0 \\
\hline & 河北 & 9 & 847 & 847 & 126 \\
\hline \multirow{2}{*}{ 内陸エリア } & 河南 & 19 & 961 & 702 & 21 \\
\hline & 桃生 & 4 & 331 & 254 & 1 \\
\hline \multicolumn{2}{|c|}{ 市街地エリア計 } & 73 & 4,174 & 2,881 & 168 \\
\hline \multicolumn{2}{|c|}{ 半島エリア計 } & 38 & 1,687 & 1,175 & 135 \\
\hline \multicolumn{2}{|c|}{ 内陸エリア計 } & 23 & 1,292 & 956 & 22 \\
\hline \multicolumn{2}{|l|}{ 合計 } & 134 & 7,153 & 5,012 & 325 \\
\hline
\end{tabular}

表-3 各地区の防集地区数

\begin{tabular}{|c|c|c|c|c|c|c|c|}
\hline \multirow{2}{*}{ 区分 } & \multirow{2}{*}{ 地区 } & \multicolumn{4}{|c|}{ 防集団地 } & \multicolumn{2}{|c|}{ 復興公営住宅 } \\
\hline & & 地区数 & 自立(戸) & 公営(戸) & 戸数計 & 地区数 & 戸数 \\
\hline 市街地エリア & 本庁 & 11 & 73 & 39 & 112 & 6 & 3,816 \\
\hline \multirow{4}{*}{ 半島エリア } & 牡鹿 & 12 & 138 & 157 & 295 & 16 & 148 \\
\hline & 雄勝 & 16 & 98 & 95 & 193 & 16 & 94 \\
\hline & 北上 & 9 & 165 & 72 & 237 & 6 & 68 \\
\hline & 河北 & $\underline{2}$ & 138 & 239 & 377 & 4 & 270 \\
\hline \multirow{2}{*}{ 内陸エリア } & 河南 & 0 & 0 & 0 & 0 & 2 & 60 \\
\hline & 桃生 & 0 & 0 & 0 & 0 & 0 & 0 \\
\hline \multicolumn{2}{|c|}{ 市街地エリア計 } & 11 & 73 & 39 & 112 & 6 & 3,816 \\
\hline \multicolumn{2}{|c|}{ 半島エリア計 } & 39 & 539 & 563 & 1,102 & 42 & 580 \\
\hline \multicolumn{2}{|c|}{ 内陸エリア計 } & 0 & 0 & 0 & 0 & 2 & 60 \\
\hline \multicolumn{2}{|l|}{ 合計 } & 50 & 612 & 602 & 1,214 & 50 & 4,456 \\
\hline
\end{tabular}

自力再建が難しい住民の受け㿼としては復興公営住宅がある。 表-3 に公営住宅の地区数と戸数を示す。市全体で 4, 456 戸, 2018 年 8 月末時点で $99.1 \%$ あたる 4,416 戸が完成した。戸数は住民 の事前登録世帯数や希望調査の状況を踏まえて決定された ${ }^{24)}$

4）地区別の戸数変動

表一4 には各地区の災害危険区域内世帯数, 仮設住宅と本設住 宅の着工戸数とそれぞれの変動を示寸。震災後は 1 世帯が 1 戸の 住宅に居住していると仮定し, 各段階・各地区における戸数の変 動を分析する。まず災害危険区域内世帯数と仮設住宅の戸数の関 係を見ると，災害危険区域内世帯数に対して仮設住宅の着工戸数 が市街地エリアでは 106.7\%であったが，半島エリアでは地区によ る差が大きい。河北地区は $258.2 \%$ と区域内世帯数の 2.5 倍であっ たが，雄勝地区では 14.1\%に留まる。

次に仮設住宅と本設住宅の戸数の関係を見ると，市街地エリア の本設住宅は仮設住宅の $94.1 \%$ と概ね同数であった。半島エリア の雄勝地区では $178.3 \%$, 牡鹿地区では $130.3 \%$ と仮設期より増加し ている。雄勝地区の住民の一部は一旦仮設期に地区外一転出して から，雄勝地区に再居住をしていることが明らかになった。一方 で本設住宅と元の災害危険区域対象世帯数を比較すると, 市街地 エリアでは $100.4 \%$ と概ね同数であった。半島エリアは河北地区で 197. 3\% と 2 倍近くに増加, 雄勝地区では $25.1 \%$ と世帯数が $1 / 4$ に 激减した。

\section{4. 雄勝地区における空間変容}

\section{(1) 雄勝地区の概要}

雄勝地区は半島エリアのうち人口減少率が最大で, 震災前の中 心市街地全域が浸水し, 災害危険区域に指定された。図一3に石 巻市全域の施設分布図 ${ }^{25)}$, 図一4 には雄勝地区の地図を示寸 ${ }^{26)}$ 。 
表一4 地区別の戸数変動

\begin{tabular}{|c|c|c|c|c|c|c|c|c|c|}
\hline \multirow[b]{2}{*}{ 区分 } & \multirow[b]{2}{*}{ 地区 } & \multirow[b]{2}{*}{$\begin{array}{l}\text { 災害危険区域 } \\
\text { 対象世帯数 }\end{array}$} & \multirow[b]{2}{*}{$\begin{array}{l}\text { 仮設住宅 } \\
\text { 着工戸数 }\end{array}$} & \multirow[b]{2}{*}{$\begin{array}{c}\text { 仮設住宅戸数/ } \\
\text { 災害危険区域対象世帯数 }\end{array}$} & \multicolumn{3}{|c|}{ 本設戸数 } & \multirow[b]{2}{*}{$\begin{array}{l}\text { 本設 } \\
\text { /仮設 }\end{array}$} & \multirow[b]{2}{*}{$\begin{array}{l}\text { 本設/災害危険 } \\
\text { 区域対象戸数 }\end{array}$} \\
\hline & & & & & \begin{tabular}{c|} 
自力 \\
(防集)
\end{tabular} & $\begin{array}{c}\text { 公営 } \\
(\text { 防集·復興公営住宅) }\end{array}$ & 計 & & \\
\hline 市街地エリア & 本庁 & 3,911 & 4,174 & $106.7 \%$ & 73 & 3,855 & 3,928 & $94.1 \%$ & $100.4 \%$ \\
\hline \multirow{4}{*}{ 半島エリア } & 牡鹿 & 705 & 445 & $63.1 \%$ & 138 & 305 & 443 & $99.6 \%$ & $62.8 \%$ \\
\hline & 雄勝 & 1,142 & 161 & $14.1 \%$ & 98 & 189 & 287 & $178.3 \%$ & $25.1 \%$ \\
\hline & 北上 & 491 & 234 & $47.7 \%$ & 165 & 140 & 305 & $130.3 \%$ & $62.1 \%$ \\
\hline & 河北 & 328 & 847 & $258.2 \%$ & 138 & 509 & 647 & $76.4 \%$ & $197.3 \%$ \\
\hline \multirow{2}{*}{ 内陸エリア } & 河南 & 0 & 961 & & 0 & 60 & 60 & $6.2 \%$ & \\
\hline & 桃生 & 0 & 331 & & 0 & 8 & 0 & $0.0 \%$ & \\
\hline 市街地エリア & 計 & 3,911 & 4,174 & $106.7 \%$ & 73 & 3,855 & 3,928 & $94.1 \%$ & $100.4 \%$ \\
\hline 半島エリア & & 2,666 & 1,687 & $63.3 \%$ & 539 & 1,143 & 1,682 & $99.7 \%$ & $63.1 \%$ \\
\hline 内陸エリア & & 0 & 1,292 & & 0 & 60 & 60 & $4.6 \%$ & \\
\hline 合計 & & 6,577 & 7,153 & $108.8 \%$ & 612 & 5,058 & 5,670 & $79.3 \%$ & $86.2 \%$ \\
\hline
\end{tabular}

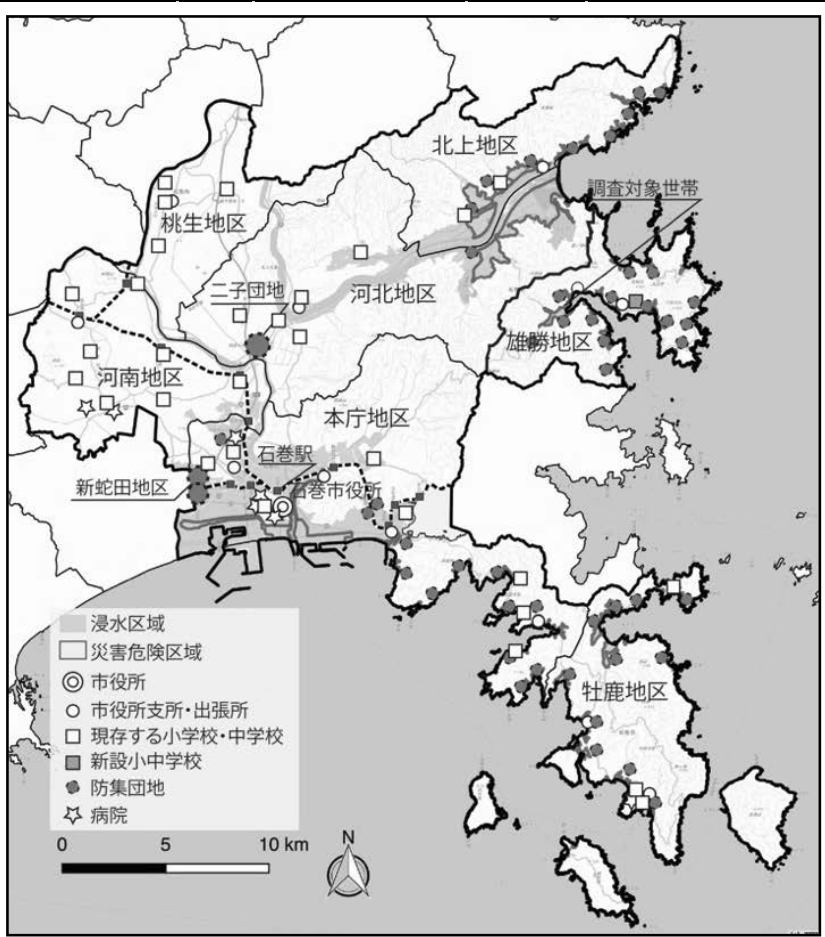

図一3 石巻市施設分布図

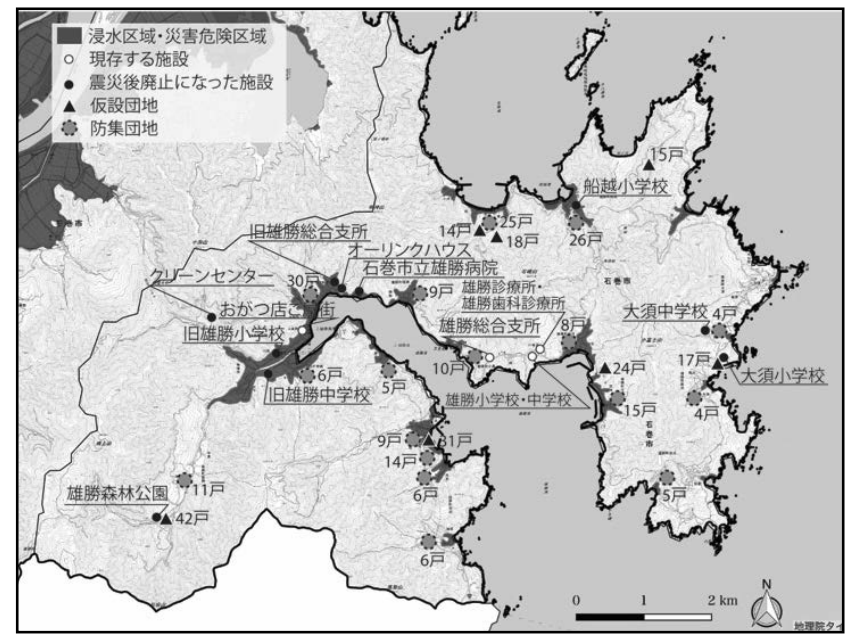

図-4 雄勝地区中心部の震災後の様子

雄勝地区の死者は 139 人，住宅被害は全壊 1,348 棟であった ${ }^{27) 。}$

雄勝地区中心部には，雄勝総合支所 (旧町役場) や公立小中学 校，病院，郵便局，銀行の支店等，行政機能やサービス機能が集 積していた。また雄勝地区には 13 の漁港と, これに付随する漁村 集落があるが，特に行政機能などが集積していた中心部が壊滅的 な被害を受けた。

\section{（2）主要施設の立地状況}

1）小中学校
震災前地区内には小学校が 4 校，中学校が 2 校存在した。この うち中心部に位置していた雄勝小学校と雄勝中学校は津波により 両校とも体育館が流出，校舎は水没に近い被害を受けた。半島北 部に位置していた船越小学校は 3 階まで浸水した。大須小学校と 中学校は津波による被害はなく, 避難所としての役割を果たし, その後 2017 年度に閉校するまでに教育活動を継続できた。しかし 雄勝小学校と中学校は河北地区の学校に間借りして2011年4月か ら再開し，統合小中学校の新設開校は 2017 年であった ${ }^{28)}$ ここの 期間は河北地区の学校への通学が必要となったため, 子育て世帯 の被災者は仮設期の居住場所として雄勝地区内の仮設住宅ではな く，河北地区か市街地エリアを選択した可能性が高い ${ }^{29)}$ 。

新たな統合小中学校は中心部からやや離れた場所に立地してい る。地区内には公共交通機関が存在しないため, 通学にはスクー ルバスまたは自家用車による移動が必要となる。

2）公共施設

地区で唯一の行政機関である雄勝総合支所は，津波により 3 階 の高さまで水没した。職員は全員屋上一避難して無事であったた め, 地震発生から 2 日後には直線距離で約 $2 \mathrm{~km}$ 内陸に位置するク リーンセンターにその機能を移した ${ }^{30)}$ 。クリーンセンターは震災 の影響でゴミの収集が停止しており，建物自体は使用可能であっ た。このように，雄勝地区内においても仮に使える土地や施設は 全くないわけではなかった。その後現在の統合小中学校の場所に 位置していた在宅介護支援センターを仮庁舎として使用した後, 2012 年 12 月からは統合小中学校から西に約 $600 \mathrm{~m}$ の仮設建物にて 業務を再開している ${ }^{31)}$ 。本設の際は公民館との複合施設となり, 建設工事が開始予定である。

また地区内には石巻市立雄勝病院が雄勝湾のほとりに位置して いた。病院は津波により 3 階建ての建物全てが水没，入院患者 40 人全員亡職員 30 人中 24 人が死亡または行方不明となった ${ }^{32)}$ 。震 災後，病院は復旧せず，現在でも地区内に病院は存在しない。診 療所と歯科診療所が 1 箇所ずつ統合小中学校の向かいで仮設建物 にて営業している。ただし診療所の診療科目は内科, 外科, 整形 外科に限られ, 診療も平日の 9 時から 16 時に限られており, 時間 外診療の受付は行われていない ${ }^{33)}$ 。なお地区内に調剤薬局はない。

3）商業施設

地区内の商業施設はほとんどが流出した。2011 年 11 月には仮 設商店街として震災前に地区内で営業していた店舗や, 地区内に 居住していた住民の新規店舗など 11 店舗がオープンした。2016 年 6 月に復興事業に伴い仮移転し，10 店舗が移転， 1 店舗は隣地 で独自に店を構えた ${ }^{34)}$ 。しかし今後はさらに高台移転地一の再度 の移動を余儀なくされるため, 本設までにかかる金銭的・精神的 負担や高齢化により閉店した店舗や，市街地エリアへと移転した 店舗も存在する。

また 2013 年 4 月に旧雄勝総合支所の近くに開店したコミュニテ イスペースとカフェと併設したオーリンクハウスは地域住民が集 まる場として重要な役割を果たしたが, 2018 年 3 月に復興事業に よる県道整備に伴い, 閉館, 解体された。 


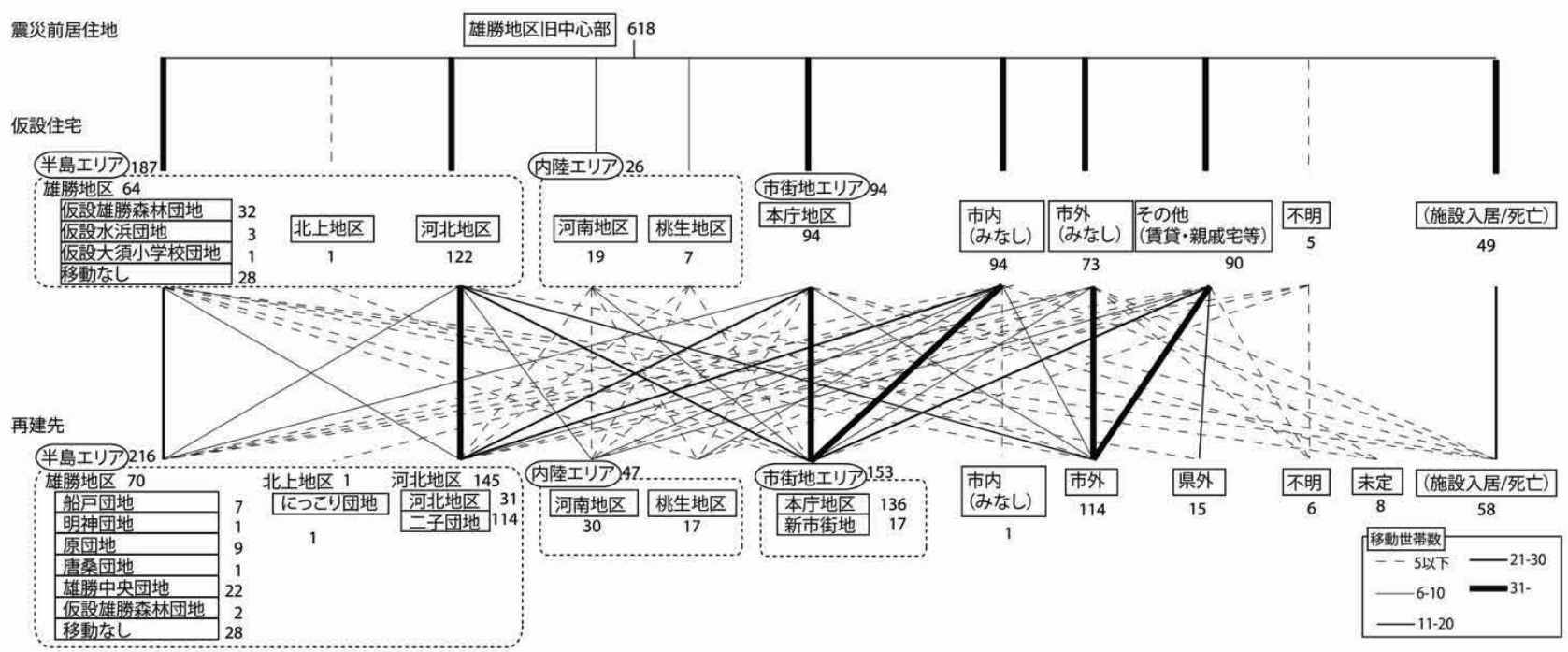

\section{5. 居住対象世帯の分析}

\section{(1) 居住形態の分析方法}

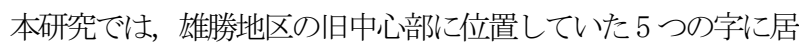
住していた住民 618 世帯の震災後の移動について, 石巻市雄勝総 合支所提供のデータに基づき分析を行った。主に仮設住宅の位置 と, 再建先の地区，再建方法について，居住地移動や方法を分析 した。なお，個人情報保護のため，元の字名の明記を避け，世帯 情報も人数のみにとどめ，旧中心部としてまとめて分析した。

\section{（2）仮設期における居住地移動}

図-5 に，雄勝地区の住民の仮設甩地から再建先への移動を示 す。ます仮設期の移動については, エリア別では半島エリアが 187 世帯と最も多く, 次に市街地エリア 94 世帯, 市内 94 世帯, その 他 90 世帯であった。半島エリアの中では河北地区が 122 世帯と最 も多く, 雄勝地区は 64 世帯であった。旧中心部 618 世帯のうち, 雄勝地区内には 28 世帯が留まり, 仮設期の段階で 49 世帯は死亡 または施設一入居したが，残りの 541 世帯がいずれかの移動を伴 ったことがわかる。

雄勝地区の仮設住宅は表一2 に示寸通り，半島エリアの中で最 も戸数が少なく 8 団地 161 戸であった。中心部に位置寸る雄勝森 林公園に整備された仮設住宅戸数は 42 戸で，このうち 32 戸が中 心部世帯であるが,これは中心部世帯全618世帯の5.2\%に留まる。 その他の世帯は, 戸数が多く居住環境の整った市街地エリアや河 北地区一移動したと考えられる。

\section{（3）本設における居住地移動}

本設の再建先については, エリア別では半島エリアが 216 世帯 と最も多く, 次に市街地エリア 153 世帯, 市外 114 世帯であった。 死亡または施設入居世帯は58 世帯であった。半島エリアの中では 河北地区が 145 世帯と最大で, 雄勝地区は70 世帯であった。

市街地エリアには図一-3に示寸, 1,229 戸が整備された新蛇田地 区のような新市街地と呼ばれる住宅地が土地区画整理事業に伴い 整備された。特に新蛇田地区では大型商業施設を取り囲むように 復興公営団地が整備された。近隣には駅や市役所の出張所, 病院 や小中学校が存在し, 雄勝地区と比較寸るとはるが生活利便性 が高い。また河北地区には，道の駅上品の郷に近い 場所に二子団 地と呼ばれる復興扵地か整備された。半島エリアの防集団地の中 では最大規模の 372 世帯が入居できる。上品の郷はレストラン, 直売所, そして温泉施設を有寸る道の駅である。震災直後には停 電や断水が発生，多くの店舗が営業を停止した中で，上品の郷は 発電装置を使い発災当日も営業を続けた。その後も近隣農家から 仕入れた農産物の販売などを行った。断水解除後の 2011 年 3 月 24 日から温泉施設が再開し, 被災者だけでなく工事関係者やボラ
ンティアも利用することができた。2013 年 10 月には石巻市と災 害時の支援協定を締結，また 2017 年にはモデル「道の駅 地域交 通拠点部門にも選出され，バス事業者との連携や総合交通戦略一 の位置付け，そして近隣を結ぶ仮設住宅路線の新設など，公共交 通を整備し，拠点としての役割を果た寸場所となった ${ }^{35)}$ 。病院人 の通院やスーパーへの買い物が便利な場所である。雄勝小学校と 中学校の間借り校舎も位置していた。以上より新蛇田地区，二子 団地いずれも既存の集客施設を軸にした新市街地整備が行われた。

雄勝地区では防集団地の位置の決定が遅孔，更に拠点となる伊 勢畑地区は地形・地質の制約により整備可能な面積・戸数が限ら れることが明らかだったため, 雄勝総合支所へのヒアリング調查 によると, 若い世帯が雄勝地区内での再建を高齢世帯などに譲り, 市街地エリアなどに居住を移さざるを得ない状況にあった。

本設期の河北地区一の移動は，河北地区からの移動が最も多い が, 次に多いのが本庁地区と市内のみなし仮設からの移動である。 河北地区は雄勝地区と市街地エリアとの中間に位置しており, 雄 勝地区の住民にとって海から遠く，か心心理的な距離が近い場所 であるため，雄勝地区一戻りたいという意向がありながらも，戻 れない世帯の受け㿼として機能したと言える。一方で仮設期の河 北地区からは市街地エリアと市外への移動も一定数存在する。

\section{（4）居住地選択の傾向}

1) 世帯数別選択

表一 5 に再建先として雄劵地区，河北地区，本庁地区，そして 市外に居住した世帯の世帯人数ごとの割合を示寸。平均世帯人数 は雄勝地区が最も低い 2.6 人, 本庁地区と市外が 2.7 人, そして 河北地区が 2.9 人であった。いずれの地区でも 1 3 人の世帯が多 く, 2 人世帯が最多である。人数の多い世帯が河北地区を選択し ている世帯が多いことから，子どもや親のいる多世代世帯が河北 地区を選択したことがわかる。

2）再建能力別選択

表一6に，地区別の再建方法を示寸。なお，震災後から移動を せずに雄勝地区一居住を続けている 28 世帯と雄勝地区の仮設住 宅に居住を続けている 2 世帯, 河北地区の再建方法が不明の 2 世 帯は除いている。防集団地（自力）は防集団地内の土地を購入し て住宅を建設した世帯，防集団地（公営）は防集団地内の公営住 宅一居住した世帯のこと, そして復興公営住宅は防集団地以外の 公営住宅への入居を意味する。

雄勝地区では㷋害危険区域が広く指定され，可住地となる低地 面積が十分に確保できなかったこともあり，自力再建世帯は存在 しない。河北地区では防集団地 (公営) が $62.9 \%$, 次いで自力再 
表一5 地区別の住民の 1 世帯あたりの人数

\begin{tabular}{|c|c|c|c|c|c|c|c|c|}
\hline 世帯人数 & \multicolumn{2}{|c|}{ 雄勝地区 } & \multicolumn{2}{|c|}{ 河北地区 } & \multicolumn{2}{|c|}{ 本庁地区 } & \multicolumn{2}{|c|}{ 市外 } \\
\hline 1人 & 15 & $21.4 \%$ & 22 & $15.2 \%$ & 32 & $20.9 \%$ & 22 & $19.3 \%$ \\
\hline 2 人 & 28 & $40.0 \%$ & 55 & $37.9 \%$ & 54 & $35.3 \%$ & 41 & $36.0 \%$ \\
\hline 3 人 & 10 & $14.3 \%$ & 28 & $19.3 \%$ & 27 & $17.6 \%$ & 21 & $18.4 \%$ \\
\hline 4人 & 7 & $10.0 \%$ & 17 & $11.7 \%$ & 20 & $13.1 \%$ & 14 & $12.3 \%$ \\
\hline 5人 & 6 & $8.6 \%$ & 11 & $7.6 \%$ & 12 & $7.8 \%$ & 11 & $9.6 \%$ \\
\hline 6人 & 3 & $4.3 \%$ & 3 & $2.1 \%$ & 6 & $3.9 \%$ & 4 & $3.5 \%$ \\
\hline 7人 & 1 & $1.4 \%$ & 7 & $4.8 \%$ & 2 & $1.3 \%$ & 1 & $0.9 \%$ \\
\hline 8人 & 0 & $0.0 \%$ & 1 & $0.7 \%$ & 0 & $0.0 \%$ & 0 & $0.0 \%$ \\
\hline 9人 & $\underline{0}$ & $0.0 \%$ & 1 & $0.7 \%$ & 0 & $0.0 \%$ & 0 & $0.0 \%$ \\
\hline 計 & 70 & $100.0 \%$ & 145 & $100.0 \%$ & 153 & $100.0 \%$ & 114 & $100.0 \%$ \\
\hline 平均世帯人数 & \multicolumn{2}{|c|}{2.6 人 } & \multicolumn{2}{|c|}{2.9 人 } & \multicolumn{2}{|c|}{2.7 人 } & \multicolumn{2}{|c|}{2.7 人 } \\
\hline
\end{tabular}

表一6 地区別の再建方法

\begin{tabular}{|l|r|r|r|r|r|r|r|r|}
\hline 再建方法 & \multicolumn{2}{|c|}{ 雄勝地区 } & \multicolumn{2}{|c|}{ 河北地区 } & \multicolumn{2}{|c|}{ 本庁地区 } & \multicolumn{2}{|c|}{ 市外 } \\
\hline 自力再建 & 0 & $0.0 \%$ & 29 & $20.3 \%$ & 82 & $53.6 \%$ & 114 & $100.0 \%$ \\
\hline 防集団地(自力) & 17 & $42.5 \%$ & 24 & $16.8 \%$ & 17 & $11.1 \%$ & 0 & $0.0 \%$ \\
\hline 防集団地(公営) & 23 & $57.5 \%$ & 90 & $62.9 \%$ & 0 & $0.0 \%$ & 0 & $0.0 \%$ \\
\hline 復興公営住宅 & 0 & $0.0 \%$ & 0 & $0.0 \%$ & 54 & $35.3 \%$ & 0 & $0.0 \%$ \\
\hline 計 & 40 & $100.0 \%$ & 143 & $100.0 \%$ & 153 & $100.0 \%$ & 114 & $100.0 \%$ \\
\hline
\end{tabular}

表一7 雄勝地区に再建した住民の再建方法

\begin{tabular}{|l|r|r|r|r|r|r|}
\hline 世帯人数 & \multicolumn{2}{|c|}{ 自力再建 } & \multicolumn{2}{|c|}{ 防集団地(自力) } & \multicolumn{2}{|c|}{ 防集団地(公営) } \\
\hline 1 人 & 0 & $0.0 \%$ & 3 & $17.6 \%$ & 7 & $30.4 \%$ \\
\hline 2 人 & 0 & $0.0 \%$ & 5 & $29.4 \%$ & 10 & $43.5 \%$ \\
\hline 3 人 & 0 & $0.0 \%$ & 3 & $17.6 \%$ & 4 & $17.4 \%$ \\
\hline 4 人 & 0 & $0.0 \%$ & 2 & $11.8 \%$ & 1 & $4.3 \%$ \\
\hline 5 人 & 0 & $0.0 \%$ & 2 & $11.8 \%$ & 1 & $4.3 \%$ \\
\hline 6 人 & 0 & $0.0 \%$ & 1 & $5.9 \%$ & 0 & $0.0 \%$ \\
\hline 7 人 & 0 & $0.0 \%$ & 1 & $5.9 \%$ & 0 & $0.0 \%$ \\
\hline 計 & 0 & $0.0 \%$ & 17 & $100.0 \%$ & 23 & $100.0 \%$ \\
\hline
\end{tabular}

表一8 河北地区に再建した住民の再建方法

\begin{tabular}{|l|r|r|r|r|r|r|}
\hline 世帯人数 & \multicolumn{2}{|c|}{ 自力再建 } & \multicolumn{2}{|c|}{ 防集団地(自力) } & \multicolumn{2}{|c|}{ 防集団地(公営) } \\
\hline 1人 & 3 & $10.3 \%$ & 0 & $0.0 \%$ & 18 & $20.0 \%$ \\
\hline 2人 & 11 & $37.9 \%$ & 5 & $20.8 \%$ & 39 & $43.3 \%$ \\
\hline 3 人 & 4 & $13.8 \%$ & 5 & $20.8 \%$ & 19 & $21.1 \%$ \\
\hline 4 人 & 3 & $10.3 \%$ & 5 & $20.8 \%$ & 8 & $8.9 \%$ \\
\hline $5 人$ & 3 & $10.3 \%$ & 5 & $20.8 \%$ & 3 & $3.3 \%$ \\
\hline 6 人 & 1 & $3.4 \%$ & 2 & $8.3 \%$ & 0 & $0.0 \%$ \\
\hline 7 人 & 3 & $10.3 \%$ & 2 & $8.3 \%$ & 2 & $2.2 \%$ \\
\hline 8 人 & 0 & $0.0 \%$ & 0 & $0.0 \%$ & 1 & $1.1 \%$ \\
\hline $9 人$ & 1 & $3.4 \%$ & 0 & $0.0 \%$ & 0 & $0.0 \%$ \\
\hline 計 & 29 & $100.0 \%$ & 24 & $100.0 \%$ & 90 & $100.0 \%$ \\
\hline
\end{tabular}

建が $20.3 \%$ であった。本庁地区では自力再建が $53.6 \%$ と約半数であ り，防集団地以外の復興住宅への入居もみられた。市外について は100\%自力再建である。

世帯人数之再建方法の関係について, 表一 7 に雄勝地区，表一8 に河北地区の值を示寸。雄勝地区は世帯人数が多い世帯が防集団 地にて自力再建を行った。一方河北地区では人数によらず再建方 法にばらつきがみられ，より多様な選択ができたことがわかる。

\section{6. まとめ·考察}

宮城県石巻市の半島エリアでは，浸水区域を元にした災害危険 区域の指定がなされ，特に雄勝地区では浸水区域の全域が災害危 険区域に指定された。震災前のまちの中心部全てが居住不可能な 空間となり，中心部に居住していた 618 世帯のうち，移動を余儀 なくされた住民が 541 世帯，87.5\%を占めていた。

雄勝地区の人口は震災前 2010 年時点で市全体の 2.5\%であり, 2.3\%の北上地区や $2.7 \%$ の牡鹿地区と同程度を占めていた。しかし 仮設住宅着工戸数は市全体の 134 団地 7, 153 戸のうち, 北上地区 3 団地 234 戸，牡鹿地区 18 団地 445 戸である一方，雄勝地区は 8 団地 161 戸と最も少なく,場所の選定等にも時間がかかったため, 同地区内住民を十分に受け入れることができなかった。仮設期の 段階で雄勝地区の住民は多い順に河北地区に 122 世帯, 本庁地区 に94 世帯が移動，雄勝地区には64 世帯が居住した。

最終的な本設先は多い順に，河北地区 145 世帯，本庁地区 136 世帯, 市外 114 世帯, そして雄勝地区は70 世帯であった。仮設期 を雄勝地区で過ごした世帯のうち 47 世帯が継続して雄勝地区に 居住，17 世帯が雄勝地区外 移動した。他地区からは23 世帯が 雄勝地区一移動した。したがって, 雄勝地区中心部に居住してい た住民618 世帯のうち，雄勝地区一再居住した世帯は，仮設期に
は施設入居等を除く 569 世帯中 64 世帯 $(11.2 \%)$, 最終的には施設 入居等を除く 560 世帯中 70 世帯 $(12.5 \%)$ であった。雄勝地区の 住民は仮設期に雄勝地区外に移動しながらも, 雄勝地区一再び居 住したいという意向があるが，戻れなかった世帯については二子 団地など近隣の大規模団地がその受け血となった。

今後は災害危険区域指定が居住地移動にどのような影響を与え たのか分析するために，より詳細な住民に対するアンケート調査 やヒアリング調査を実施し，指定地域と未指定地域における住民 の居住地選択の動向を明らかにしていきたい。

謝辞:本研究では、石巻市雄勝総合支所に多大なるご協力をいただ きました。記して御礼申し上げます。

\section{補注及び引用文献}

1) 国土地理院(2011.4.18), 津波による浸水範用の面積(概略值)について(第5 報) 2) 岩手県・宮城県・福島県各市町村HPより筆者算出 なおデータは2017 年時点 3)国土交通省, 東日本大震災の被災地で行われる防災集団移転促進事業

4) 朝日新聞(2016.3. 18)，（復興へ 震災 6 年目:1）防災集讨移転促進事業 かかる時間, かさむ支出/岩手県

5)朝日新聞(2017. 10.27), 移転後活用，100ヘクタール決まらず 防災集団移転，土地点 在が壁/宮城県

6)復興庁(2015),防集移転元地の活用に関する事例集

7) 松本英里·姥浦道生(2015), 東日本大震災後の災害危険区域の指定に関寸る研究, 都市 計画論文集, 50(3), 1273-1280

8) 荒木裕子・北後明彦 (2014), 東日本大震災の津波浸水地における災害危険区域の指定 と人的被害・住家被害及び可住地割合の関連分析, 神戸大学大学院工学研究科・シス テム情報学研究科紀要, 6, 24-31

9) 荒才笙子・秋田典子(2016), 千葉県旭市の津波被災地を対象とした現地復興の実態に 関する研究, ランドスケープ研究, 79(5), 611-616

10) 荒木笙子・秋田典子(2017), 津波被苂地において復興土地区画整理事業が住民の居 住地選択に与えた影響 岩手県釜石市 $\mathrm{A}$ 地区を事例として，都市計画論文集 $52(3), 1088-1093$

11)佃悠他(2017), 災害公営住宅入居登録者の登録までの住宅再建意向変化とその要因, 日本建築学会計画系論文集, $82(731), 1-9$

12) 1908 年から 2015 年までの国勢調査データを基に作成。

13) 2016 年 12 月，石巻市雄勝総合支所と千葉大学大学院園芸学研究科は，東日本大震 災からの復興に関する研究, 施策, 記録の作成等を通じた地域社会の復興に寄与寸る ための連携・協力に関する協定書を締結した。

14) 石巻市建設部都市計画課, 平成 29 年度 石巻の都市計画 (資料)

15)消防庁(2018 年9月7日), 東北地方太平洋沖地震 (東日本大震災)について(第158 報) 16)国土数值情報, 地理院地図, 国勢調査より作成

17) 読売新聞, 2012. 12. 02, 石巻市が㷋害危険区域指定，宮城県十木部, 2012.3，東日本 大震災 1 年の記録 (みやぎの住宅社会資本再生・復興の歩み) , 全国都道府県市区町 村別面積調 ※なお挌地区面積は合併当時の值を使用したため, 合計值が現在の市域 面積と若干異なる。

18)石巻市, 2011 年 12 月, 石巻市震㷋復興基本計画

19)読売新聞, 2011 年 5 月 10 日, 仮設住宅需要 1 万戸減

20)読売新聞, 2011 年 5 月 10 日, 牡鹿半島に仮設住宅建設 石巻市が丘陵地造成へ二宮城

21) 石巻市ホームページ, 仮設住宅関係の掀知らせを元に筆者作成

$\langle$ http://www. city. ishinomaki. lg. jp/cont/10401200/7625/7625. html〉 更新日:2018.09.03, 閲覽日 $\cdot 2018.9 .16$

22 ) 宮城県, 第 1 回夕やぎ地域復興支援会議(石巻) (2014 年 9 月 10 日)資料，地域住民主 体の震災復興まちづくり

23)石巻市ホームページ, 石巻市の主な復興事業のスケジュール(2018 年 8 月 1 日現在) 〈http://www. city. ishinomaki. lg. jp/cont/10181000/8235/0001/20140930161952. html〉 を元に筆者作成, 更新日:2018.9.10, 閲覧日:2018.9.16

24) 石巻市ホームページ, 石巻市の主な復興事業のスケジュール(2018 年 8 月 1 日現在) $\langle$ http://www. city. ishinomaki. lg. jp/cont/10181000/8235/0001/20140930161952. html〉, 更新日:2018.9. 10, 閲覧日:2018.9. 16, 石巻市, 石巻市災害復興住宅要求計画(案) 2018 年 3 月改定，宮城県ホームページ，災害公営住宅の整備計画について (2018 年 8 月 31 日現在)，更新日:2018.9.11，閲覧日:2018.9.16

$\langle$ https://www. pref. miyagi. jp/site/ej-earthquake/seibi joukyoul. html〉

25）地理院地図をベースに, 国土数值情報より市域データ, 市区町村役場データ, 復興支 援調査アーカイブより浸水区域データ, 石巻市資料をもとに災害危険区域を使用し， さらにGoogle Maps や宮城県ホームページ等を元に施設をプロットして作成した。

26) 地理院地図をべースに, 国土数值情報より市域データ, 市区町村役場データ, JMC50m メッシュ(標高) 2014 年 8 月 1 日発行(承認番号 平成 26 情複より等高線デー夕, 復興 支援調査アーカイブより浸水区域データを使用し,さらにGoogle Maps や宮城県ホー ムページ等を元に施設をプロットして作成した。

27 ) 石巻市(2011 年 12 月), 石巻市震災復興基本計画

28) 石巻市教育委員会(2012), 石巻市立学校施設災害復旧整備計画

29)朝日新聞(2011 年4月 29 日), (消失した街の跡形 : 5) 旧雄勝町〈宮城県石巻市〉

30) 齋藤泰 (2013), 東日本大震災における石巻市雄勝総合支所の対応, 消防科学と情 報, $113,60-64$

31) 重川希志依・田中聡(2013) 市町村合併が災害対応にもたらした影響分析一東日本大震 災時の石巻市を事例として-, 地域安全学会梗概集, 32, 113-116

32 )河北新報(2013 年1月 3 日), 第 1 部・あの日何が…(1) 石巻市雄勝病院/迫る海, まさか屋上まで

33)石巻市ホームページ, 市立診療所，更新日:2018.9.20，閲覧日;2018.9.22 〈http://www. city. ishinomaki. lg. jp/cont/10351000/20130326085946. html〉

34 ) 石巻がく (2016 年5月 11 日), おがつ店こ屋街, 新仮設へ 県道工事に伴い移車云

35)国土交通省東北地方整備局(2017. 11.22)，平成 29 年度 モデル「道の駅」(地域交 通拠点部門）の認定について 